\title{
INITIAL GROWTH OF Araucaria angustifolia (Bertol.) Kuntze IN RESPONSE TO FERTILIZATION WITH NITROGEN, PHOSPHORUS AND POTASSIUM
}

\author{
Valdeci Constantino ${ }^{1 *}$, Julierme Zimmer Barbosa ${ }^{2}$, Antônio Vargas Motta ${ }^{3}$, Marcos Antonio Dolinski ${ }^{4}$, Stephen \\ Arthur Prior ${ }^{5}$, Flávio Zanette ${ }^{1}$. \\ ${ }^{1}$ Federal University of Paraná, Department of Phytotechnology and Phytosanitary, Curitiba, Paraná, Brazil - deco@ufpr.br*; flazan@ufpr.br \\ ${ }^{2}$ Ingá University Center (Uningá), Department of Agronomy, Maringá, Paraná, Brazil - barbosajz@yahoo.com.br \\ ${ }^{3}$ Federal University of Paraná, Department of Soils and Agricultural Engineering, Curitiba, Paraná, Brazil - mottaufpr@gmail.com \\ ${ }^{4}$ University Tuiuti of Paraná, Curitiba, Paraná, Brazil - marcos.dolinski@utp.br \\ ${ }^{5}$ USDA-ARS, National Soil Dynamics Laboratory, Auburn, Alabama, USA - steve.prior@ars.usda.gov
}

Received for publication: 17/01/2018 - Accepted for publication: 03/04/2018

\begin{abstract}
The objective of this study was to evaluate N, P and K requirements for initial growth of A. angustifolia, as well as symptoms of nutritional deficiency. Three experiments were conducted to evaluate growth response of the species to N, P and $\mathrm{K}$ application. Five rates of each element were tested individually. $\mathrm{P}$ and $\mathrm{K}$ were applied once by mixing with soil before transplanting seedlings, and $\mathrm{N}$ was divided into three applications. Six-month-old seedlings ( $20 \mathrm{~cm}$ height) were transplanted into pots containing $16 \mathrm{dm}^{-3}$ of soil. The response to nutrient applications was monitored by measuring plant height and basal diameter for 16 months. At the conclusion of the experiment, seedling dry mass (roots, needles, branches, and stem), seedling quality index, and nutritional deficiency symptoms were evaluated. Chlorophyll relative index (CRI) and needle color were also measured in the $\mathrm{N}$ experiment. Increased plant quality was only observed for $\mathrm{N}$ (up to $1.238 \mathrm{mg} \mathrm{dm}^{-3}$ ) and $\mathrm{P}$ fertilization (up to $472 \mathrm{mg} \mathrm{dm}^{-3}$ ). Small needles, chlorotic, and premature death of lower branches were the main symptoms for $\mathrm{N}$ deficiency, while dark green needle coloration, sparse secondary branches, and short internodes characterized $\mathrm{P}$ deficiency. Results suggest that nursery applications of $\mathrm{N}$ and $\mathrm{P}$ are required to improve the growth and quality of plants.
\end{abstract}

Keywords: Seedling production, conifers, deficiency symptoms, macronutrients.

\section{Resumo}

Crescimento inicial de Araucaria angustifolia (Bertol.) Kuntze fertilizadas com nitrogênio, fósforo $e$ potássio. $\mathrm{O}$ objetivo deste trabalho foi avaliar os requisitos de $\mathrm{N}, \mathrm{P}$ e $\mathrm{K}$ no crescimento inicial de $A$. Angustifolia, bem como os sintomas de deficiência nutricional. Foram realizados três experimentos para avaliar a resposta de crescimento da espécie às aplicações de N, P e K. Cinco taxas de cada elemento foram testadas individualmente. $\mathrm{P}$ e $\mathrm{K}$ foram aplicados uma vez, misturando-se com o solo antes do transplantio das mudas, e $\mathrm{N}$ foi dividido em três aplicações. Mudas de seis meses com $20 \mathrm{~cm}$ de altura foram transplantadas para potes contendo $16 \mathrm{dm}^{-3}$ de solo. A resposta às aplicações de nutrientes foi monitorada medindo-se a altura da planta e o diâmetro basal durante 16 meses. Na conclusão do experimento, foram avaliadas a massa seca de plantas (raízes, agulhas, ramos e caule), índice de qualidade das plântulas e sintomas de deficiência nutricional. $\mathrm{O}$ índice relativo de clorofila (CRI) e a cor das acículas também foram medidos no experimento com N. O aumento da qualidade da planta foi observado para fertilização com N (até $1.238 \mathrm{mg} \mathrm{dm}^{-3}$ ) e P (até $472 \mathrm{mg} \mathrm{dm}^{-3}$ ). Acículas pequenas, cloróticas e a morte prematura de ramos inferiores foram os principais sintomas de deficiência de $\mathrm{N}$, enquanto a coloração verde escura das acículas, ramos secundários escassos e entrenós curtos caracterizaram a deficiência de P. Os resultados sugerem que as aplicações de $\mathrm{N}$ e $\mathrm{P}$ nas condições de viveiro são necessárias para melhorar o crescimento e a qualidade das plantas.

Palavras-chave: Produção de mudas, coníferas, sintomas de deficiência, macronutrientes.

\section{INTRODUCTION}

Araucaria angustifolia, commonly known as araucaria, Paraná pine or Brazilian pine, is considered to be the most important conifer of the Brazilian flora. This species is native to the Southern Brazilian plateau. It represents $40 \%$ of the plants of the Araucaria Forest and occupies the upper forest stratum (KOCH; CORRÊA, 2010).

Due to intense exploitation, A. angustifolia forests have been reduced to small fragments (MONTAGNA et al., 2012). Additionally, most of these remaining fragments were subjected to logging and removal of the best quality trees. This reduction has resulted in a decrease of the quality of the forest, therefore it 
is necessary to introduce seedlings of good genetic quality. Thus, the chances of survival of the species have also decreased to the point of being classified as species in extinction process (IUCN, 2013). Moreover, the traditional gathering of $A$. angustifolia edible nuts (i.e. pinhão), which is still allowed and commonly practiced (PERALTA et al., 2016), can also interfere with the natural A. angustifolia regeneration. These factors combined with the rarity of species plantations increase the risk of extinction. Considering the species socioeconomic and environmental importance, creating plantations aimed to produce pine nuts and/or wood from selected progenies is critical for its survival (WENDLING et al., 2017a; WENDLING et al., 2017b).

Although A. angustifolia occurs in several soil types, it has fertility requirements comparable to Pinus spp (SILVA et al., 2001). Low fertility and shallow soils are associated with slow growth of species during early growth (CARVALHO, 2003). Silva et al. (2001) reported that A. angustifolia height is directly related to soil N, $\mathrm{P}$, and K, suggesting that the lack of these elements limits growth (SIMÕES; COUTO, 1973; MOREIRASOUZA; CARDOSO, 2002). The application of $6 \mathrm{~kg} \mathrm{~m}^{-3}$ of slow release fertilizer (containing macro and micronutrients) resulted in best growth of A. angustifolia seedlings after nine months (ROSSA et al., 2011). However, individual nutrient requirements could not be determined since N, P, and $\mathrm{K}$ were applied together in this study. Most Brazilian soils are very poor in $\mathrm{P}$ and exhibit a high capacity of $\mathrm{P}$ fixation, which restricts plant availability (ROY et al., 2016).

Management of $A$. angustifolia for commercial plantations should begin at the nursery, since wellnourished and quality seedlings should ensure favorable growth in field planting. However, efforts related to the production of seedlings of the species are still incipient. Would the growth of the plants be favored by fertilization? The objective of this study was to assess the requirements of $\mathrm{N}, \mathrm{P}$, and $\mathrm{K}$ during early growth of $A$. angustifolia and to document symptoms of nutritional deficiency.

\section{MATERIALS AND METHODS}

The present study was conducted in an outdoor nursery located in Curitiba, state of Paraná, Brazil (latitude $=-25.412$; longitude $=-49.428$; altitude $=911 \mathrm{~m}$ ). Experiments started in December 2013, using $20 \mathrm{dm}^{-3}$ plastic pots (height $=30 \mathrm{~cm}$; lower diameter $=25 \mathrm{~cm}$; upper diameter $=35 \mathrm{~cm}$ ) filled with a Cambisol collected from an area of natural $A$. angustifolia occurrence (Pinhais; latitude $=-25.38$; longitude $=-49.12$; altitude $=920 \mathrm{~m}$ ). The granulometry and chemical attributes of the soil are presented in Table 1 and indicate poor soil in relation to $\mathrm{P}$ and $\mathrm{K}$ (SBCS, 2004).

Table 1. Soil granulometric and chemical properties before planting A. angustifolia seedlings ${ }^{1}$.

Tabela 1. Granulometria e propriedades químicas do solo antes do plantio das mudas de A. angustifolia ${ }^{I}$.

\begin{tabular}{|c|c|c|c|c|c|c|c|c|c|c|c|c|c|}
\hline Sand & Silt & Clay & pH & $\mathrm{Ca}^{2+}$ & $\mathrm{Mg}^{2+}$ & $\mathbf{K}^{+}$ & $\mathbf{A l}^{3+}$ & $\mathrm{H}+\mathrm{Al}^{3+}$ & CEC & BS & $\mathbf{m}$ & $\mathbf{P}$ & OC \\
\hline ------- & $\mathrm{g} \mathrm{kg}^{-1}$ & & & & 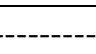 & & $\mathrm{l}_{\mathrm{c}} \mathrm{dm}$ & & ----- & $\%$ & $\%$ & $\mathrm{mg} \mathrm{dm}^{-3}$ & $\mathrm{~g} \mathrm{dm}^{-3}$ \\
\hline 238 & 213 & 550 & 4.0 & 1.60 & 0.80 & 0.08 & 2.90 & 11.30 & 13.78 & 18 & 54 & 0.90 & 4.20 \\
\hline
\end{tabular}

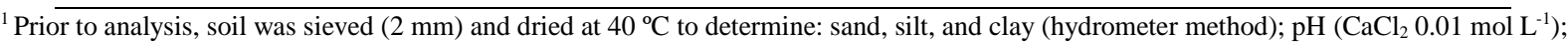
$\mathrm{Ca}^{2+}, \mathrm{Mg}^{2+}, \mathrm{Al}^{3+}$ (extracted with $\mathrm{KCl} 1 \mathrm{~mol} \mathrm{~L}^{-1}$ ); $\mathrm{H}+\mathrm{Al}^{3+}$ (calcium acetate $0.5 \mathrm{~mol} \mathrm{~L}^{-1}$ extraction); organic carbon (OC) (volumetric method by potassium dichromate); $\mathrm{K}^{+}$and $\mathrm{P}$ (Mehlich-1 extraction); base saturation (BS); cation exchange capacity (CEC) at $\mathrm{pH} 7$; and $\mathrm{Al}^{3+}$ saturation (m). All analyses were based on Embrapa (2011).

The soil used was sieved ( $4 \mathrm{~mm}$ ), and $3.6 \mathrm{~g}$ of dolomitic lime (75.2\% neutralizing power) per kilogram of soil was applied based on chemical analysis in order to raise the base saturation to $70 \%$. After lime application, the soil was homogenized and incubated for two months.

The three experiments had five treatments with four replications each, in a completely randomized design: Experiment I investigated five rates of $\mathrm{N}\left(0,158,315,624\right.$, and $\left.1238 \mathrm{mg} \mathrm{dm}^{-3}\right)$ with fixed rates of $\mathrm{P}\left(469 \mathrm{mg} \mathrm{dm}^{-3}\right)$ and $\mathrm{K}\left(469 \mathrm{mg} \mathrm{dm}^{-3}\right)$; Experiment II investigated five rates of $\mathrm{P}(0,117,234,469$, and $\left.938 \mathrm{mg} \mathrm{dm}^{-3}\right)$ with fixed rates of $\mathrm{N}\left(624 \mathrm{mg} \mathrm{dm}^{-3}\right)$ and $\mathrm{K}\left(469 \mathrm{mg} \mathrm{dm}^{-3}\right)$; and Experiment III investigated five rates of $\mathrm{K}\left(0,117,234,469\right.$, and $\left.938 \mathrm{mg} \mathrm{dm}^{-3}\right)$ with fixed rates of $\mathrm{N}\left(624 \mathrm{mg} \mathrm{dm}^{-3}\right)$ and $\mathrm{P}\left(469 \mathrm{mg} \mathrm{dm}^{-3}\right)$. The respective sources used to provide $\mathrm{N}, \mathrm{P}$, and $\mathrm{K}$ were: urea $(45 \% \mathrm{~N})$; triple superphosphate $\left(41 \% \mathrm{P}_{2} \mathrm{O}_{5}\right)$; and $\mathrm{K}$ chloride $\left(60 \% \mathrm{~K}_{2} \mathrm{O}\right)$.

The rates of $\mathrm{N}$ indicated above correspond to the total amount used in the first and second years. Half was applied at the installation of the experiment (December 2013). The remainder was divided into three $(25,15$, and 10\%) and applied every 60 days, starting from December 2014. N, P, or K fixation was based on the fourth 
dose tested for each element. The purpose was favoring the growth of plants while the requirement of the other elements was evaluated.

Respective amounts of $\mathrm{N}$ (50\% total amount), $\mathrm{P}$, and $\mathrm{K}$ for each treatment were applied to $16 \mathrm{dm}^{-3}$ of soil, followed by homogenization before filling the pot. Seven-months-old A. angustifolia seedlings (height $\sim 20$ $\mathrm{cm}$ ) were transplanted into pots on December $13^{\text {th }}, 2013$. The pots were randomly distributed in the nursery and placed on a plastic surface in order to avoid contact with underlying soil. Weed control was performed manually. Irrigation occurred as necessary, especially during periods of no rainfall, by adding approximately two liters of water to each pot in the morning.

Evaluations of plant height and basal diameter (42, 75, 123, 181, 215, 244, 303, 332, 368, 456, and 526 days after transplanting) started on January 2014 until May 2015 (16 months). On September 2015, five mature needles were cut from each branch of last internode and brought to the laboratory. Their length and width were measured by a digital caliber (four digits). By using a graduated scale, the length of the largest branch of the first whorl of the crown base and the longest internode from each plant were measured.

Three needles were also collected from $\mathrm{N}$ Experiment in order to measure relative chlorophyll index (RCI) by a chlorophyll meter (CCM-200 plus - Opti-Sciences). In addition, the same needles were measured by color with a spectrophotometer (Konica Minolta, Spectrophotometer CM-5) to assess their relation to the calculated Hue angle. On November 2015, plants were harvested and divided into roots, needles, branches, and stems. Each fraction was oven dried $\left(60^{\circ} \mathrm{C}\right)$ until constant mass. The ratio of root mass and shoot dry mass was calculated according to Silva (2012).

Soil samples from each pot were obtained for chemical analysis (Table 2) according to Embrapa (2011).

Table 2. Soil chemical properties after harvesting A. angustifolia seedlings. ${ }^{1}$

Tabela 2. Propriedades químicas do solo após a colheita das mudas de A. angustifolia ${ }^{1}$.

\begin{tabular}{|c|c|c|c|c|c|c|c|c|c|c|c|c|c|c|c|}
\hline \multirow{2}{*}{ Variables } & \multicolumn{5}{|c|}{-----Rates of $\mathrm{N}\left(\mathrm{mg} \mathrm{dm}^{-3}\right)$-------- } & \multicolumn{5}{|c|}{------Rates of P $\left(\mathrm{mg} \mathrm{dm}^{-3}\right)$------ } & \multicolumn{5}{|c|}{-----Rates of K $\left(\mathrm{mg} \mathrm{dm}^{-3}\right)$----- } \\
\hline & $\mathbf{0}$ & 158 & 315 & 624 & 1238 & $\mathbf{0}$ & 118 & 233 & 469 & 938 & $\mathbf{0}$ & 117 & 234 & 469 & 938 \\
\hline $\mathrm{pH}-\mathrm{CaCl}_{2}$ & 5.5 & 5.6 & 5.3 & 4.6 & 4.3 & 4.8 & 5.0 & 4.9 & 4.8 & 4.8 & 4.4 & 4.7 & 4.9 & 4.8 & 4.5 \\
\hline Carbon $\left(\mathrm{g} \mathrm{dm}^{-3}\right)$ & 6.7 & 5.1 & 10.6 & 7.8 & 10 & 4.3 & 4.7 & 5.8 & 6.8 & 3.0 & 8.9 & 8.7 & 8.4 & 10.7 & 9.5 \\
\hline $\mathrm{P}\left(\mathrm{mg} \mathrm{dm} \mathrm{d}^{-3}\right)$ & 30.0 & 35.4 & 37.9 & 45.6 & 34.7 & 1.4 & 7.5 & 16.4 & 58.2 & 135.6 & 34.8 & 43.6 & 42.7 & 43.5 & 50.1 \\
\hline $\mathrm{K}^{+}\left(\mathrm{cmol}_{\mathrm{c}} \mathrm{dm}^{-3}\right)$ & 0.50 & 0.48 & 0.42 & 0.30 & 0.21 & 0.41 & 0.38 & 0.45 & 0.37 & 0.33 & 0.07 & 0.11 & 0.15 & 0.28 & 0.69 \\
\hline
\end{tabular}

${ }^{1}$ Prior to analysis, soil was sieved $(2 \mathrm{~mm})$ and dried at $40^{\circ} \mathrm{C}$ to determine: $\mathrm{pH}\left(\mathrm{CaCl}_{2} 0.01 \mathrm{~mol} \mathrm{~L}^{-1}\right)$; organic carbon (OC) (volumetric method by potassium dichromate); and $\mathrm{K}^{+}$and $\mathrm{P}$ (Mehlich-1 extraction).

The Dickson Quality Index (DQI) was used to evaluate seedling quality (DICKSON et al., 1960). Data were subjected to analysis of variance, and effects of $\mathrm{N}, \mathrm{P}$, and $\mathrm{K}$ rates were determined by regression analysis. The choice of regressions (linear or quadratic) was based on the highest coefficient of determination $\left(\mathrm{R}^{2}\right)$ and probability (p) values. For all analyses, the statistical software Assistat 7.7 was used.

\section{RESULTS}

\section{Experiment I: Nitrogen fertilization}

No difference in the height of $A$. angustifolia seedling due to $\mathrm{N}$ fertilization was found for both high growth (spring and summer) and low growth (autumn and winter) seasons. Five-hundred twenty-six days after initial $\mathrm{N}$ application, the average plant height was $72.2 \mathrm{~cm}$ (Figure 1A). Needle width and length responded differently to $\mathrm{N}$ application. Needle width increased and reached a maximum value of $725 \mathrm{mg} \mathrm{N} \mathrm{dm}^{-3}$, whereas the average needle length of $36 \mathrm{~mm}$ was not affected by $\mathrm{N}$ rate (Figure 1B).

Mass of aboveground fractions (needles, branches and stem), roots, and total seedling dry mass increased linearly due to $\mathrm{N}$ supply (Figures 1C, 1D and 1F). The largest proportion of aboveground matter was formed by needles, $64 \%$ higher than the stem fraction and almost three times higher than the branch fraction (Figure 1C). Similar growth of belowground and aboveground portions of the seedling resulted in a root-to-shoot ratio close to 1:1 (Figure 1D). Seedling quality as measured by DQI showed a linear improvement due to $\mathrm{N}$ fertilization (Figure 1F).

$\mathrm{N}$ supply influenced needle color (i.e., greenness) according to Hue angle values and attained maximum value at $903 \mathrm{mg} \mathrm{N} \mathrm{dm}^{-3}$ (Figure 1E). The RCI also increased and reached maximum value at $664 \mathrm{mg} \mathrm{N} \mathrm{dm}^{-3}$. We observed some symptoms of $\mathrm{N}$ deficiency during the study. The main symptoms were generalized needle chlorosis (beginning in older needles), smaller needle size, and premature death of lower branches (Figure 2).

FLORESTA, Curitiba, PR, v. 49, n. 1, p. 099-108, jan/mar. 2019

Constantino. V. et.al. 

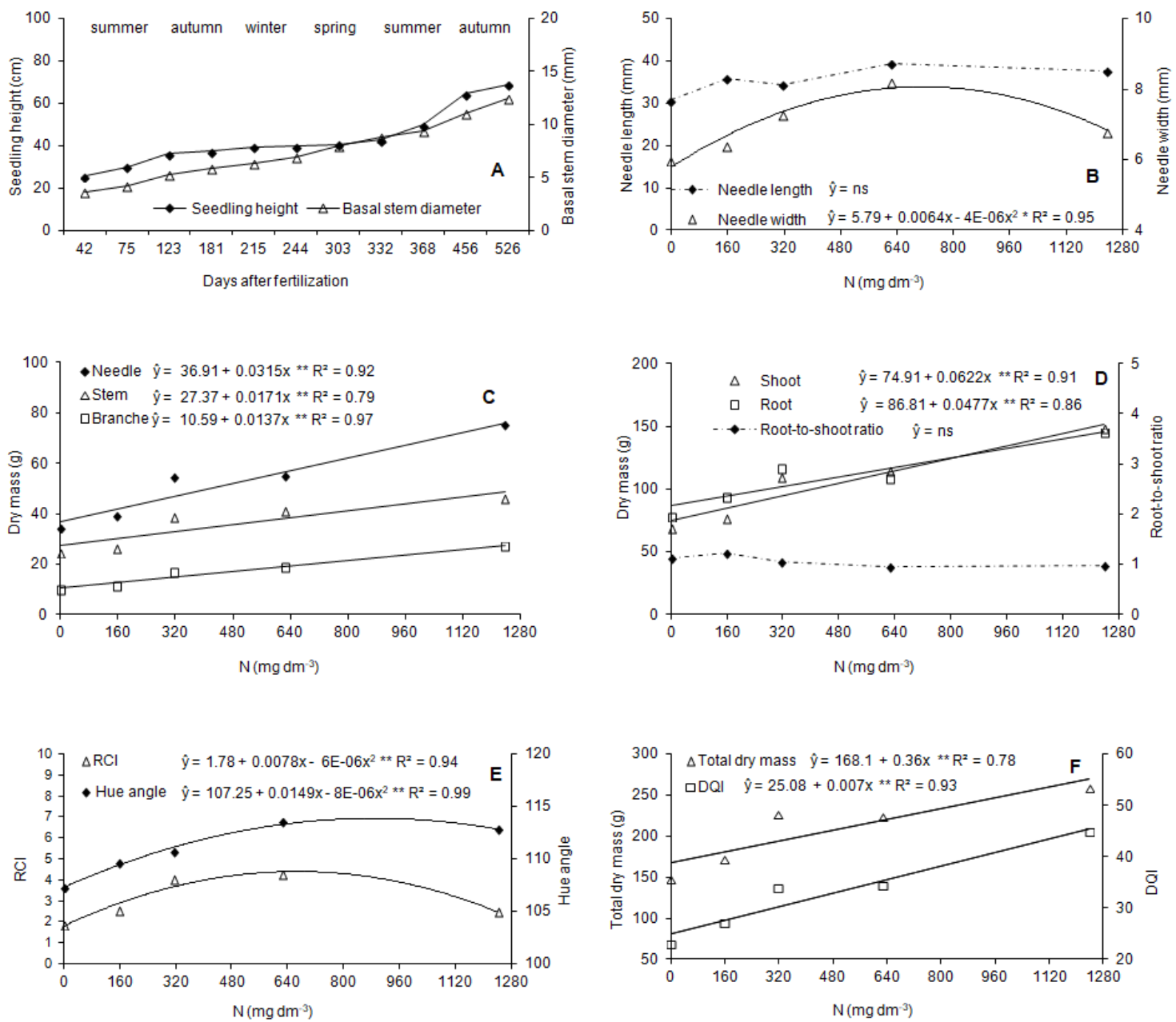

Figure 1. Effect of nitrogen fertilization on growth and quality attributes of A. angustifolia seedlings. $\mathrm{RCI}=$ Relative chlorophyll index; DQI $=$ Dickson quality index; significance $=* \mathrm{p}<0.05 ; * * \mathrm{p}<$ 0.01 .

Figura 1. Efeito da adubação nitrogenada sobre os atributos de crescimento e qualidade das mudas de A. angustifolia. $\mathrm{RCI}=$ índice relativo de clorofila; $\mathrm{DQI}=$ índice de qualidade de Dickson; significância $=* \mathrm{p}<0,05 ; * * \mathrm{p}<0,01$.

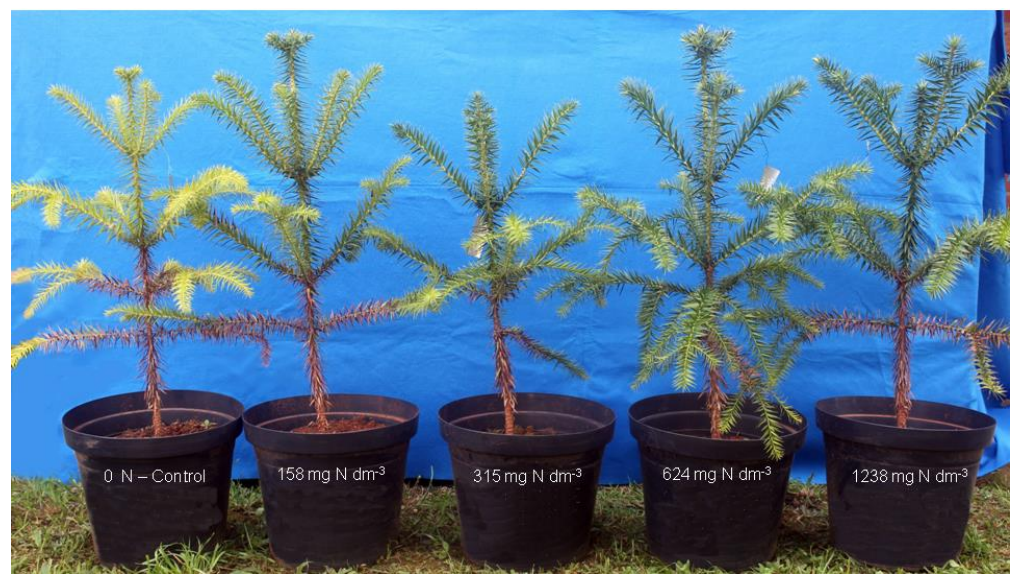

Figure 2. A. angustifolia fertilized with different levels of $\mathrm{N}$ and fixed rates of $\mathrm{P}\left(469 \mathrm{mg} \mathrm{dm}^{-3}\right)$ and $\mathrm{K}(469 \mathrm{mg}$ $\left.\mathrm{dm}^{-3}\right)$ at 21 months-old. 
Figura 2. A. angustifolia fertilizadas com diferentes níveis de $\mathrm{N}$ e taxas fixas de $\mathrm{P}\left(469 \mathrm{mg} \mathrm{dm}^{-3}\right)$ e $\mathrm{K}(469 \mathrm{mg}$ $\mathrm{dm}^{-3}$ ) aos 21 meses de idade.

\section{Experiment II: Phosphate fertilization}

There was a significant difference for most of the evaluated parameters. Phosphorus fertilization promoted significant growth in height and basal stem diameter at 170 and 320 days after application, respectively (Figure 3A and 3B). At 526 days, average height of $87.8 \mathrm{~cm}$ and basal stem diameter of $14.4 \mathrm{~mm}$ were observed, and both variables exhibited a linear response to $\mathrm{P}$ addition (Figure $3 \mathrm{C}$ ). At the highest $\mathrm{P}$ rate, height and diameter were $49 \%$ and $26 \%$ higher than the control, respectively (Figure 3C).

Aboveground dry mass was influenced by $\mathrm{P}$ supply (Figure 3D). Quadratic responses to $\mathrm{P}$ were observed for needle and branch mass, whereas stem mass response was linear. Total dry matter and DQI showed a quadratic response with maximum values at $574 \mathrm{mg} \mathrm{P} \mathrm{dm}^{-3}$ and $474 \mathrm{mg} \mathrm{P} \mathrm{dm}^{-3}$, respectively (Figure 3F).

Although needle width and length were not altered by $\mathrm{P}$ addition, needle dry mass was positively responsive until $697 \mathrm{mg} \mathrm{P} \mathrm{dm}^{-3}$. Branch dry mass reached its maximum at $638 \mathrm{mg} \mathrm{P} \mathrm{dm}^{-3}$. In addition, the length of the largest branch and internode exhibited quadratic $\left(35.16+0.0321 \mathrm{x}-3 \mathrm{E}-05 \mathrm{x}^{2} \mathrm{p}<0.01, \mathrm{R}^{2}=0.70\right)$ and linear $\left(15.96+0.0079 x \mathrm{p}<0.01, \mathrm{R}^{2}=0.63\right)$ responses, respectively.

Whereas aboveground dry mass had a linear response to $\mathrm{P}$ and roots exhibited a quadratic response, the root-to-shoot ratio showed a linear decrease to $\mathrm{P}$ addition (Figure $3 \mathrm{E}$ ). When the supply reached $472 \mathrm{mg} \mathrm{P} \mathrm{dm}^{-3}$, it corresponded to $\sim 125 \mathrm{~g}$ of root and shoot dry matter (ratio of 1:1).
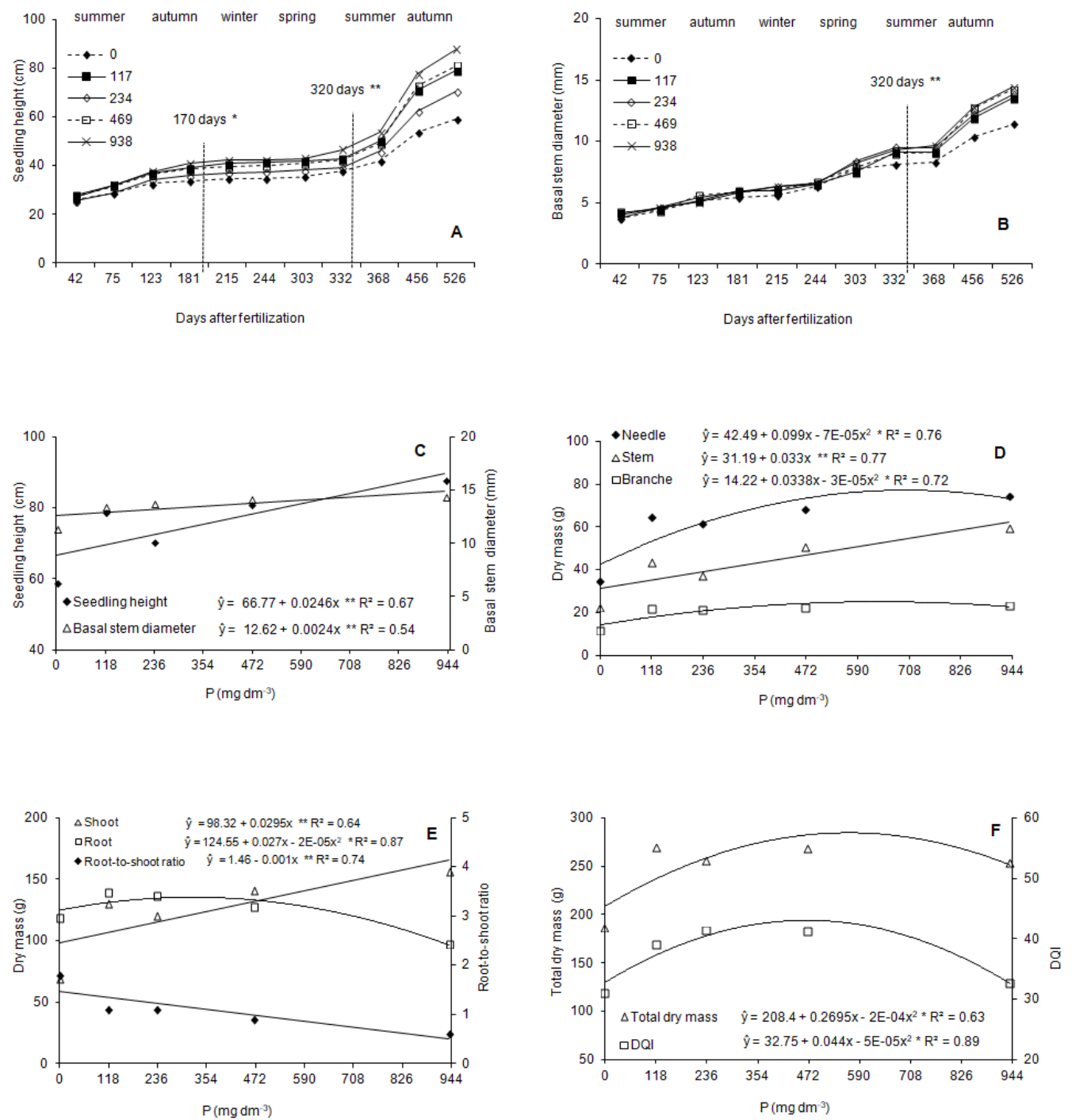

FLORESTA, Curitiba, PR, v. 49, n. 1, p. 099-108, jan/mar. 2019 
Figure 3. Effect of phosphate fertilization on growth and quality attributes of A. angustifolia seedlings. $\mathrm{DQI}=$ Dickson Quality Index; significance: $* \mathrm{p}<0.05 ; * * \mathrm{p}<0.01$.

Figura 3. Efeito da adubação fosfatada sobre os atributos de crescimento e qualidade das mudas de $A$. angustifolia. DQI = Índice de Qualidade de Dickson; significância: $* \mathrm{p}<0,05 ; * * \mathrm{p}<0,01$.

$\mathrm{P}$ deficiency symptoms were evident in the control treatment (no $\mathrm{P}$ addition). The main symptoms were dark green needle coloration, scarcity of secondary branches, under developed apical buds, and shorter internode segments in relation to the other treatments (Figure 4).

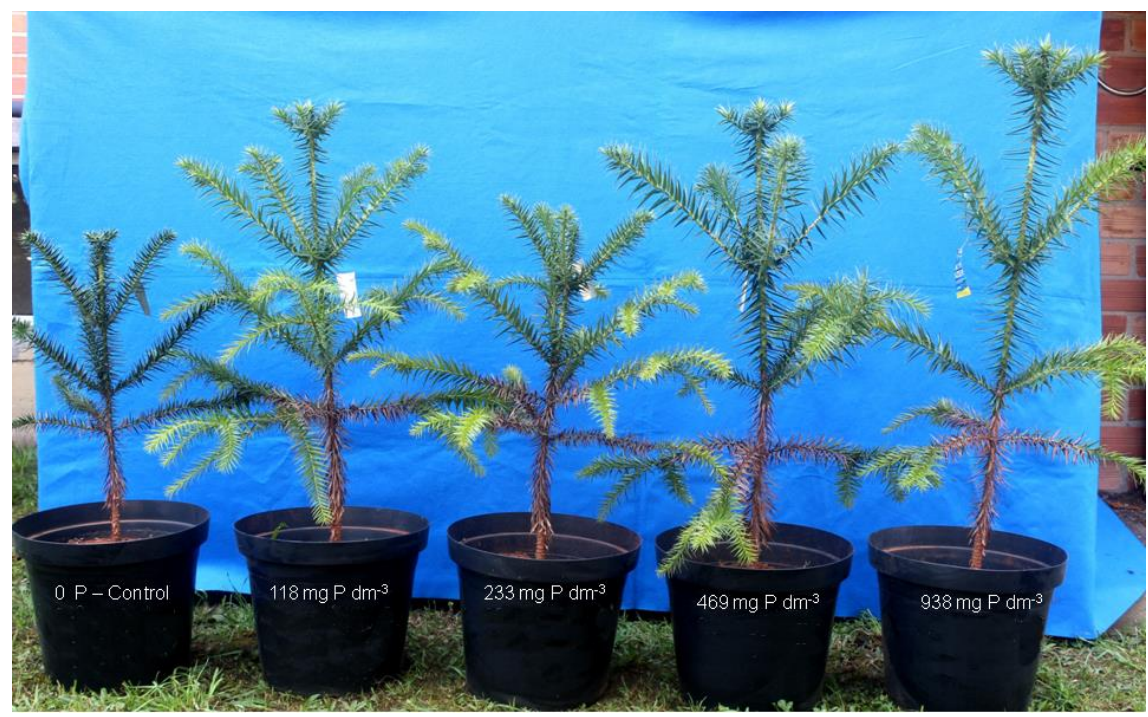

Figure 4. A. angustifolia fertilized with different levels of $\mathrm{P}$ and fixed rates of $\mathrm{N}\left(624 \mathrm{mg} \mathrm{dm}^{-3}\right)$ and $\mathrm{K}(469 \mathrm{mg}$ $\mathrm{dm}^{-3}$ ) at 21 months-old.

Figura 4. A. angustifolia fertilizadas com diferentes níveis de $\mathrm{P}$ e taxas fixas de $\mathrm{N}\left(624 \mathrm{mg} \mathrm{dm}^{-3}\right)$ e $\mathrm{K}(469 \mathrm{mg}$ $\mathrm{dm}^{-3}$ ) aos 21 meses de idade.

\section{Experiment III: Potassium fertilization}

There was no effect of $\mathrm{K}$ fertilizer on growth and seedling quality attributes (Table 3). Furthermore, seedlings did not exhibit any $\mathrm{K}$ deficiency symptoms (Figure 5). The lack of an overall growth response suggested that background soil levels were adequate for early growth stages of A. angustifolia seedlings.

Table 3. Effect of potassium fertilization on growth and quality of A. angustifolia seedlings at 21 months-old. Tabela 3. Efeito da fertilização com potássio no crescimento e na qualidade de mudas de A. angustifolia aos 21 meses de idade.

\begin{tabular}{|c|c|c|c|c|c|c|c|c|c|c|c|c|}
\hline \multirow{2}{*}{$\begin{array}{c}\mathbf{T} \\
\left(\mathrm{mg} \mathrm{dm}^{-3}\right)\end{array}$} & \multirow{2}{*}{$\begin{array}{c}\mathbf{H} \\
(\mathrm{cm})\end{array}$} & \multirow{2}{*}{$\begin{array}{c}\mathbf{D} \\
(\mathrm{mm})\end{array}$} & \multicolumn{2}{|c|}{------Needles----- } & \multirow{2}{*}{ Needles } & \multirow[t]{2}{*}{ Stem } & Branches & \multirow{2}{*}{ TS } & \multirow[t]{2}{*}{ Roots } & \multirow{2}{*}{ TDM } & \multirow[t]{2}{*}{ R:S } & \multirow[t]{2}{*}{ DQI } \\
\hline & & & $\mathrm{W}(\mathrm{mm})$ & $\mathrm{L}(\mathrm{cm})$ & & & -- Dry mas & & & & & \\
\hline 0 & $73.8 \mathrm{~ns}$ & $14.6 \mathrm{~ns}$ & $3.8 \mathrm{~ns}$ & $8.0 \mathrm{~ns}$ & $69.3 \mathrm{~ns}$ & $24.7 \mathrm{~ns}$ & $52.5 \mathrm{~ns}$ & $147 \mathrm{~ns}$ & $110 \mathrm{~ns}$ & $257 \mathrm{~ns}$ & $0.8 \mathrm{~ns}$ & $38.1 \mathrm{~ns}$ \\
\hline 117 & 70.8 & 13.2 & 3.6 & 7.3 & 58.5 & 18.1 & 45.7 & 122 & 95 & 217 & 0.8 & 33.2 \\
\hline 234 & 73.6 & 14.4 & 3.7 & 7.7 & 73.3 & 25.3 & 52.6 & 151 & 125 & 276 & 0.8 & 41.9 \\
\hline 469 & 81.8 & 14.9 & 4.5 & 7.9 & 77.5 & 23.1 & 62.2 & 163 & 117 & 280 & 0.7 & 38.7 \\
\hline 938 & 75.9 & 13.3 & 3.7 & 7.4 & 65.9 & 24.0 & 50.4 & 140 & 117 & 258 & 0.8 & 39.3 \\
\hline
\end{tabular}

T: treatment; H: height; D: diameter; W: width; L: length; TS: total shoot mass; TDM: total dry mass; R:S: root-to-shoot ratio; DQI: Dickson quality index; ns: not significant. 


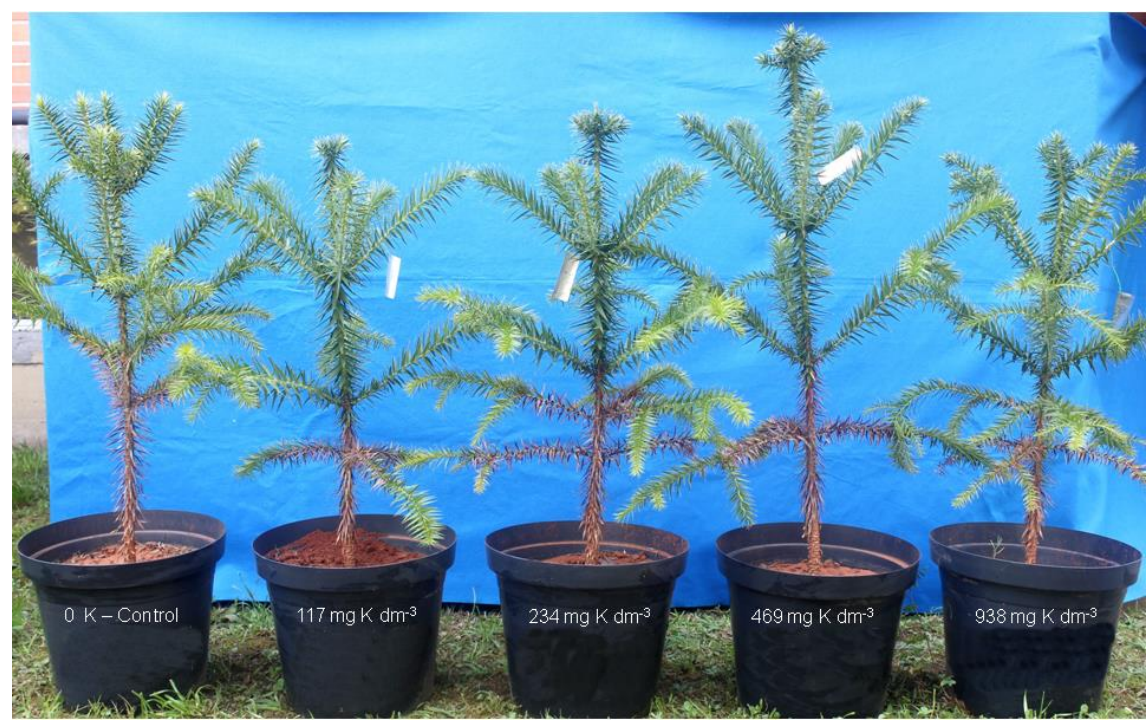

Figure 5. A. angustifolia fertilized with different levels of $\mathrm{K}$ and fixed rates of $\mathrm{N}\left(624 \mathrm{mg} \mathrm{dm}^{-3}\right)$ and $\mathrm{P}(469 \mathrm{mg}$ $\mathrm{dm}^{-3}$ ) at 21 months-old.

Figura 5. A. angustifolia fertilizadas com diferentes níveis de $\mathrm{K}$ e taxas fixas de $\mathrm{N}\left(624 \mathrm{mg} \mathrm{dm}^{-3}\right)$ e $\mathrm{P}(469 \mathrm{mg}$ $\mathrm{dm}^{-3}$ ) aos 21 meses de idade.

\section{DISCUSSION}

\section{Experiment I: Nitrogen fertilization}

Height and basal stem diameter of $A$. angustifolia seedlings were not sensitive to $\mathrm{N}$ addition (Figure 1A) in contrast to results found by Simões and Couto (1973). Differences between the studies may be related to degree of $\mathrm{N}$ availability, since these authors used a sand substrate that may have imposed a higher restriction on supplying $\mathrm{N}$ to seedlings. However, other attributes of growth and quality of the seedling (Figures 1 and 2) highlight the importance of $\mathrm{N}$ in plant nutrition for the production of A. angustifolia seedlings. The low organic matter in the Cambisol used in our study (Table 1) probably contributed to the positive growth response upon $\mathrm{N}$ addition.

$\mathrm{N}$ fertilization enhanced dry mass in aboveground fractions (Figure 1C) and roots (Figure 1D) to a similar degree, with no alterations in root-to-shoot ratio (Figure 1D). According to Caldeira et al. (2008), the root-to-shoot ratio suitable for red Brazilian peppertree (Schinus terebinthifolius) is 1:2. In this regard, the noted relation would be adequate for out-planting A. angustifolia seedlings to the field since aboveground standing biomass must not be much greater than corresponding root biomass in order to avoid possible problems related to water demands of early aboveground growth. In addition, it is important that out-planted seedlings are taller than surrounding bush in order to reduce competition and increase chances for survival.

The main photosynthetic pigment (chlorophyll) contains $\mathrm{N}$ in its structure (TAIZ et al., 2015). Changes in RCI with $\mathrm{N}$ addition (Figure 1E) suggest that some $\mathrm{N}$ assimilated was not directed to chlorophyll molecules since this index exhibited quadratic response. Taiz et al. (2015) report that 50 to $70 \%$ of $\mathrm{N}$ in the whole leaf is in chlorophyll and enzymes. Thus, there is a limit to the $\mathrm{N}$ use in these components.

The $\mathrm{N}$ uptake above plant needs could be understood as a form of luxury consumption. However, this may not be totally true in the case of A. angustifolia since total dry mass responded linearly to $\mathrm{N}$ supply, which indicates the $\mathrm{N}$ use in physiological growth processes. This can be clearly seen in the linear response of DQI between treatments as shown in Figure 1F. The maximum value of $1,238 \mathrm{mg} \mathrm{dm}^{-3}$ reflects the best quality plants that showed a good allometric balance.

In the control treatment (no added $\mathrm{N}$ ), deficiency symptoms displayed by A. angustifolia seedlings were similar to those reported by Simões and Couto (1973) for the same species. As mentioned previously, $\mathrm{N}$ is a chlorophyll component (green color pigment); thus, needle concentrations in the range of 6.9 to $8.9 \mathrm{~g} \mathrm{~N} / \mathrm{kg}$ (data not shown) resulted in deficiency symptoms in 21-month-old A. angustifolia seedlings. The lack of this element results in yellowish needles, initially observed in older leaves due to translocation to younger needles (HAWKESFORD et al., 2012). This $\mathrm{N}$ translocation is also related to the premature death of inferior branches (Figure 2). The inhibition of needle and branch growth occurs due to the need for $\mathrm{N}$ in the formation of proteins and enzymes related to newer growth. 


\section{Experiment II: Phosphate fertilization}

The $\mathrm{P}$ effect observed in seedling growth was expected due to the very low amount of $\mathrm{P}$ available in the soil (Table 1), which is indicative of many soils found in tropical environments (ROY et al., 2016). Studies of $A$. angustifolia by Simões and Couto (1973) and of Ilex paraguariensis by Barbosa et al. (2018) corroborated our results. These studies reported that height and basal stem diameter increased as P levels increased. Statistical differences in seedling height, which resulted from application, started to appear after 170 days (Figure 3A). Seedling P reserves could have delayed the response to P addition until further growth stages. After 320 days, increases in both plant height and basal stem diameter (Figures 3A and 3B) intensified P demand of expanding aboveground and belowground systems (HAWKESFORD et al., 2012).

On the one hand, needle mass represented branch growth since more branches supported larger numbers of needles (Figure 3D). Moreover, stem mass seemed to show the linear increase in height and basal stem diameter. Internodes were 69\% higher than the treatment in which P was not applied (control; data not shown). On the other hand, branch dry mass was directly related to branch length (data not shown), as both variables exhibited a quadratic response. Significant gains observed in all aboveground fractions illustrated that $A$. angustifolia was responsiveness to P supply, similar to results reported by Santos et al. (2008).

Changes in root-to-shoot ratio with P supply showed adjustments in shoot and root growth for nutrient acquisition (Figure 3E). Cell division in the main taproot tends to reduce under low levels of $\mathrm{P}$ in order to favor lateral root initiation. Therefore, $\mathrm{P}$ deficiency leads to increases in lateral roots and root hairs in plants (HAWKESFORD et al., 2012). As P became more available (or intercepted by roots), aboveground growth increased (linear) and root growth decreased (quadratic), which led to a linear decrease in the root-to-shoot ratio (Figure 3E). This demonstrates the importance of root growth and architecture in soil exploration for P. When P supply reached $472 \mathrm{mg} \mathrm{P} \mathrm{dm}^{-3}$ (corresponding to $\sim 125 \mathrm{~g}$ of roots dry mass), the ratio of 1:1 was indicative of a balance between root and aboveground growth. This is important for plant quality and is reflected in the DQI (Figure 3F). From this point, the ratio continues to decrease while aboveground growth continues to increase as reflected by changes in seedling height.

Symptoms of phosphorus deficiency observed in control plants of A. angustifolia (Figure 4) were generally similar to those reported by Simões and Couto (1973), who found chlorosis in older needles. This result was not present in our study (Figure 4). This chlorosis was observed under extreme deficit conditions due to the growth of seedlings in sand using a liquid nutrient solution. The Cambisol substrate used in our study may have enabled some mycorrhizal associations (MOREIRA-SOUZA; CARDOSO, 2002), which can result in phosphate solubilizing bacteria in the rhizosphere that can enhance $\mathrm{P}$ availability (MOREIRA-SOUZA; CARDOSO, 2002; RIBEIRO; CARDOSO, 2012). The concentration of P in control needles ranged from 1.0 to $1.2 \mathrm{~g} / \mathrm{kg}^{-1}$ of dry matter (data not shown). This result was related to the observed deficiency symptoms and may be utilized as a reference in posterior studies.

\section{Experiment III: Potassium fertilization}

The absence of response to $\mathrm{K}$ application occurred despite the low soil availability. No foliar deficiency symptoms were observed in contrast to the observations for $\mathrm{N}$ and $\mathrm{P}$ experiments. In contrast, Simões and Couto (1973) reported positive responses from seedlings of A. angustifolia grown in sand with K in the nutrient solution. It is worth noting that their experiment was conducted under conditions of $\mathrm{K}$ deficiency. In our experiment, the results suggest that $A$. angustifolia was able to extract enough $\mathrm{K}$ from soil to meet initial seedling demands.

Potassium can be found in soil in the forms of solution, exchangeable, non-exchangeable, and structural. K-solution and K-exchangeable forms are generally associated with plant availability, but absorption can occur only from soil solution. Due to the exhaustion of other available forms, non-exchangeable $\mathrm{K}$ and some structural forms can be released, varying among soil types (VIEIRA et al., 2017; HAWKESFORD et al., 2012). Non-exchangeable $\mathrm{K}$ forms may be associated with low response to $\mathrm{K}$ for some tree species (VIEIRA et al., 2016). Furthermore, gymnosperms can have a low demand for $\mathrm{K}$, as illustrated by the low concentration (4.3 to $5.2 \mathrm{~g} / \mathrm{kg}$ ) observed in our needles of unfertilized seedlings (data not shown).

Whereas we found no differences in K treatments, Simões and Couto (1973) reported that seedlings of A. angustifolia with $\mathrm{K}$ deficiency showed lower height, altered branch angles, and smaller old leaves with yellowing at the extremities. For seedlings of A. angustifolia that received no $\mathrm{K}$ and had low levels in needles, Barbosa et al. (2017) reported an abnormal increase of Ca oxalate crystal formation in needles and $\mathrm{Ca}$ in the mesophyll. Although added $\mathrm{K}$ did not alter the growth of A. angustifolia seedlings (Figure 5), it is worth noting that our study was conducted under ideal moisture conditions, which does not often occur in the field. Thus, it is 
possible that seedlings of $A$. angustifolia with low leaf $\mathrm{K}$ content may face some limitations under periods of drought since this nutrient can impact various physiological functions (e.g., opening and closing of stomata, photosynthesis, assimilation/transport, and enzyme activity) (TAIZ et al., 2015).

\section{CONCLUSION}

- $\quad$ Nursery applications of $\mathrm{N}$ and $\mathrm{P}$ are required to improve A. angustifolia growth and quality.

- Generalized chlorosis of the needles (beginning with older leaves), smaller needle size, and premature death of lower branches were the main symptoms of $\mathrm{N}$ deficiency. Seedlings with $\mathrm{P}$ deficiency exhibited dark green needle coloration, sparse secondary branches, and short internodes.

- No response was observed for $\mathrm{K}$ fertilization in growth and quality of A. angustifolia seedlings, which suggests low $\mathrm{K}$ requirements in the initial growth stages. However, further tests are necessary to determine if a minimum $\mathrm{K}$ rate should be used to produce $A$. angustifolia seedlings, ensuring that they respond well to environmental stress under field conditions.

\section{REFERENCES}

BARBOSA, J. Z.; CONSTANTINO, V.; ZANETTE, F.; MOTTA, A. C. V.; PRIOR, S. A. Soil fertility affects elemental distribution in needles of the conifer Araucaria angustifolia: A microanalytical study. Cerne, v. 23 , n. 2, p. 257-266, 2017.

BARBOSA, J. Z.; MOTTA, A. C.; CONSAlTER, R.; POGGERE, G. C.; SANTIN, D.; WENDLING, I. Plant growth, nutrients and potentially toxic elements in leaves of yerba mate clones in response to phosphorus in acid soils. Anais da Academia Brasileira de Ciências, v. 40, n. 1, p. 557-571, 2018.

CALDEIRA, M. V. W.; ROSA, G. N. da; FENILli, T. A. B.; HARBS, R. M. P. Composto orgânico na produção de mudas de aroeira-vermelha. Scientia Agraria, Curitiba, v. 9, n. 1, p. 27-33, 2008.

CARVALHO, P. E. R. Espécies arbóreas brasileiras. Brasília: Embrapa Informação Tecnológica; Colombo, PR: Embrapa Florestas, 2003. 1039 p.

DICKSON, A.; LEAF, A. L.; HOSNER, J. F. Quality appraisal of white spruce and white pine seedling stock in nurseries. Forest Chronicle, v. 36, n. 1, p. 10-13, 1960.

EMPRESA BRASILEIRA DE PESQUISA AGROPECUÁRIA-EMBRAPA. Manual de métodos de análise de solo. 2. ed. Embrapa Solos, 2011, p. 225.

HAWKESFORD, M.; HORST, W.; KITCHEY, T.; LAMBERS, H.; SCHJOERRING, J.; MOLLER, I. S.; WHITE, P. Functions of macronutrients. In: MARSCHNER, P. (ed.). Marschner's mineral nutrition of higher plants. Ed. 3. Elsevier science, 2012. p. 135-189.

IUCN (International Union for Conservation of Nature and Natural Resources). The IUCN Red List of Threatened Species: Araucaria angustifolia (published in 2013). Disponível em: <http://dx.doi.org/10.2305/IUCN.UK.2013-1.RLTS.T32975A2829141.en>. Acesso em: 20/02/2017.

KOCH, Z.; CORRÊA, M. C. Araucária: a floresta do Brasil Meridional. 2. ed. Curitiba: Olhar Brasileiro, 2010. $168 \mathrm{p}$.

MONTAGNA, T.; FERREIRA, D. K.; STEINER, F.; SILVA, F. A. L. S. da; BITTENCOURT, R.; SILVA, J. Z. da; MANTOVANI, A.; REIS, M. S. dos. A importância das unidades de conservação na manutenção da diversidade genética de araucária no Estado de SC. Biodiversidade Brasileira, v. 2, n. 2, p. 17-24, 2012.

MOREIRA-SOUZA, M.; CARDOSO, E. J. B. N. Dependência micorrízica de Araucaria angustifolia (Bert.) O. Ktze. sob doses de fósforo. Revista Brasileira de Ciência do Solo, v. 26, p. 905-912, 2002.

PERALTA, R. M.; KOEHNLEIN, E. A.; OLIVEIRA, R. F.; CORREA, V. G.; CORRÊA, R. C. G.; BERTONHA, L.; BRACHT, A.; FERREIRA, I. C. F. R. Biological activities and chemical constituents of Araucaria angustifolia: An effort to recover a species threatened by extinction. Trends in Food Science \& Technology 54, p. 85-93, 2016.

RIBEIRO, C. M.; CARDOSO, E. J. B. N. Isolation, selection and characterization of root-associated growth promoting bacteria in Brazil pine (Araucaria angustifolia). Microbiological Research, v. 167, p. 69-78, 2012. 
ROSSA, Ü. B.; ANGElO, A. C.; NOGUEIRA, A. C.; REISSMANN, C. B.; GROSSI, F.; RAMOS, M. R. Fertilizante de liberação lenta no crescimento de mudas de Araucaria angustifolia e Ocotea odorifera. Floresta, V. 41, n. 3, p. 491-500, 2011.

ROY, E. D.; RICHARDS, P. D.; MARTINELli, L. A.; COLETTA, L. D.; LINS, S. R. M.; VAZQUEZ, F. F.; WILLING, E.; SPERA, S. A.; VANWEY, L. K.; PORDER, S. The phosphorus cost of agricultural intensification in the tropics. Nature Plants 2, n. 16043, 2016. Disponível em: <https://www.nature.com/articles/nplants201643>. Acesso em: 22/08/2017.

SANTOS, J. Z. L.; RESENDE, A. V.; NETO, A. E. F.; CORTE, E. F. Crescimento, acúmulo de fósforo e frações fosfatadas em mudas de sete espécies arbóreas nativas. Revista Árvore, v. 32, n. 5, Viçosa, set./out. 2008.

SILVA, D. D.; KANE, M. E.; BEESON JR, R. C. Changes in root and shoot growth and biomass partition resulting from differente irrigation intervals for Ligustrum japonicum Thunb. HortScience, v. 47, n. 11, p. 16341640, 2012.

SILVA, H. D.; BELlOTE, A. F. J.; FERREIRA, C. A.; BOGNOLA, I. A. Recomendações de solos para Araucaria angustifolia com base nas suas propriedades físicas e químicas. Boletim de Pesquisa Florestal, Colombo, n. 43, p. 61-74, jul./dez. 2001.

SIMÕES, J. W.; COUTO, H. T. Z. Efeitos da omissão de nutrientes na alimentação mineral do pinheiro do Paraná Araucaria angustifolia (Bert) O. Ktze. cultivado em vaso. Instituto de Pesquisas Florestais, n. 7, p. 339, 1973.

SBCS. Manual de adubação e de calagem para os Estados do Rio Grande do Sul e de Santa Catarina / Sociedade Brasileira de Ciência do Solo. Comissão de Química e Fertilidade do Solo. - 10. ed. - Porto Alegre, 2004. 400 p. : il.

TAIZ, L.; ZEIGER, E.; MØLlER, I. M.; MURPHY, A. Plant physiology and development. Sinauer Associates, 2015, $761 \mathrm{p}$.

VIEIRA, C. R.; WEBER, O. L. dos S.; SCARAMUZZA, J. F. Omissão de macronutrientes no crescimento inicial de Tabebuia ochraceae. Ambiência, v. 12, p. 869-883, 2016.

VIEIRA, M. S.; OLIVEIRA, F. H. T. de; SANTOS, H. C.; MEDEIROS, J. D. S. de. Capacidade de suprimento de potássio em doze classes de solos em função de cultivos sucessivos de milho. Revista de Ciências Agrárias/Amazonian Journal of Agricultural and Environmental Sciences, v. 59, n. 3, p. 219-227, 2017.

WENDLING, I.; STUEPP, C. A.; ZANETTE, F. Produção de mudas de araucária por estaquia e miniestaquia. In: WENDLING, I; ZANETTE, F. (Ed.). Araucária: particularidades, propagação e manejo de plantios. 1. ed. Embrapa, 2017. p. 65-106, a.

WENDlinG, I.; ZANETTE, F.; RICKLI-HORSTI, H. C.; CONSTANTINO, V. Produção de mudas de araucária por enxertia. In: WENDLING, I; ZANETTE, F. (Ed.). Araucária: particularidades, propagação e manejo de plantios. 1. ed. Embrapa, 2017. p. 65-106, b. 